\title{
Xanthine oxidoreductase is present in human synovium
}

\author{
R E Allen, J M OUTHWAite, C J MORRIS, AND D R BLAKE \\ From the Rheumatism Research Wing, The Medical School, Birmingham
}

SUMmARY It is postulated that the mobile inflamed joint may be subject to cyclical ischaemic reperfusion injury. Xanthine oxidoreductase is an enzyme thought to contribute to oxidative reperfusion injury, and the detection of this activity in human synovium is described. Three normal and five rheumatoid tissues were assayed with a carbon-14 radioassay detecting the conversion of $\left[{ }^{14} \mathrm{C}\right]$ xanthine to $\left[{ }^{14} \mathrm{C}\right]$ uric acid. Rheumatoid synovia contained $0 \cdot 67-305 \mu \mathrm{U} / \mathrm{g}$ tissue $(n=5)$, while normal synovia contained $1 \cdot 2-5 \cdot 0 \mu \mathrm{U} / \mathrm{g}$ tissue $(n=3)$.

Key words: reperfusion, ischaemia, ischaemic reperfusion, xanthine oxidase, xanthine, rheumatoid arthritis.

We have previously suggested a mechanism involving ischaemic reperfusion injury to account for the unusual persistence of synovial inflammation. ${ }^{1}$ This involved synovial ischaemia induced by exercise and reperfusion injury occurring on resting. In resting inflamed joints with an effusion, intra-articular pressures are raised compared with those of normal joints, but during exercise the pressure in these joints increases further. ${ }^{2}$ Lund-Olsen showed that partial pressures of oxygen $\left(\mathrm{Po}_{2}\right)$ in the synovial fluid are lower in rheumatoid joints than in osteoarthritic or traumatised joints and fall during exercise. ${ }^{3}$ It is probable that, as the pressures measured during exercise often exceed the capillary perfusion pressure and indeed are greater than systolic blood pressure, ${ }^{24}$ occlusion of the vessels supplying the synovium occurs, explaining the drop in synovial fluid $\mathrm{Po}_{2}$. Once exercise has ceased intra-articular pressures drop and $\mathrm{PO}_{2}$ levels rise, often above basal levels, consistent, not only with reflow through the synovial vascular bed, but with a reactive hyperaemia.

In many tissues much of the damage resulting from an ischaemic incident has been attributed to the postischaemic reperfusion phase ${ }^{5}$ the ischaemic phase 'priming' the cells for the destructive activity occurring in the reperfusion phase. During temporary ischaemia low oxygen concentrations halt mitochondrial oxidative phosphorylation, and cellu-

Accepted for publication 19 May 1987.

Correspondence to Dr D R Blake, Rheumatism Research Wing, The Medical School, Birmingham B15 2TJ. lar adenosine triphosphate (ATP) production becomes dependent on anaerobic glycolysis. This is an inefficient means of ATP production from glucose and also results in the production of lactic acid. Increasing levels of lactic acid together with an increasing ratio of $\mathrm{NADH}$ to $\mathrm{NAD}^{+}$(due to ceased oxidative phosphorylation) eventually lead to the inhibition of glycolysis, and intracellular ATP and ADP levels, already reduced, fall further. ${ }^{6}{ }^{7}$ Among other events the decrease in intracellular ATP and ADP concentration leads to increases in concentrations of adenosine and its breakdown products, including hypoxanthine and xanthine, ${ }^{7}$ these last two being substrates for the enzyme xanthine oxidoreductase.

Xanthine oxidoreductase is a cytosolic enzyme normally oxidising hypoxanthine and xanthine to uric acid and reducing $\mathrm{NAD}^{+}$to NADH. Della Corte and Stirpe described the conversion of this enzyme from the normal $\mathrm{NAD}^{+}$dependent ' $D$ ' form to an $\mathrm{NAD}^{+}$independent ' $\mathrm{O}$ ' form, for which oxygen can act as an electron acceptor forming the superoxide anion $\left(\mathrm{O}_{2}^{--}\right)$and consequently hydrogen peroxide $\left(\mathrm{H}_{2} \mathrm{O}_{2}\right) .{ }^{8}\left(\mathrm{H}_{2} \mathrm{O}_{2}\right.$ is also produced directly by this enzyme.) This conversion has been reported to occur in ischaemia and may be mediated by a calcium dependent mechanism. ${ }^{910}$ Upon reperfusion, the $O$ form of the enzyme, supplied with oxygen as an electron acceptor, and high levels of hypoxanthine, produces a flux of $\mathrm{O}_{2}^{--}$which may be converted either spontaneously or by the enzyme superoxide dismutase to $\mathrm{H}_{2} \mathrm{O}_{2}$. 
Electron paramagnetic resonance studies have shown the formation of radicals in the reperfusion phase of ischaemic damage in other tissues, particularly the heart, ${ }^{11}$ and tissue injury has been reduced by the addition of radical scavengers such as superoxide dismutase, catalase, and mannitol. ${ }^{10} 12$ Iron chelators $^{12}$ and allopurinol ${ }^{13}$ (which on oxidation to oxypurinol by xanthine oxidoreductase is a potent inhibitor of the enzyme) also have beneficial effects in hypoxic reperfusion injury.

The detection of xanthine oxidoreductase in human synovium is therefore of importance as a first step in the investigation of possible mechanisms of radical generation peculiar to a reperfusion phase of synovial injury.

\section{Materials and methods}

Human knee synovium was obtained postoperatively, loosely wrapped with aluminium foil, and frozen in liquid nitrogen. Rheumatoid synovium was obtained from patients requiring joint replacement or synovectomy and non-arthritic samples from patients requiring amputation for malignancy. Samples were stored at $-70^{\circ} \mathrm{C}$. The tissue was powdered by grinding with a pestle and mortar cooled with liquid nitrogen. The powdered tissue was then mixed with buffer $(0 \cdot 1 \mathrm{M}$ TRIS/HC1, $\mathrm{pH}$ $8 \cdot 3,4^{\circ} \mathrm{C}, 1 \mathrm{~g}$ tissue $+4 \mathrm{ml}$ buffer) containing the protease inhibitors phenylmethylsulphonyl fluoride (PMSF; $0.1 \mathrm{mmol} / \mathrm{l}$ ) and $N$-p-tosyl-Larginine methyl ester (TAME; $1 \mathrm{~g} / \mathrm{l}$ ) and sonicated two $30 \mathrm{~s}$ bursts with $30 \mathrm{~s}$ cooling) at $4^{\circ} \mathrm{C}$ in an MSE $150 \mathrm{~W}$ sonicator using an MSE titanium microprobe. The preparation was then centrifuged $(100000 \mathrm{~g}$, one hour, $4^{\circ} \mathrm{C}$ ) and the clear supernatant beneath the fatty upper layer retained. The xanthine oxidoreductase activity of the supernatant was then measured according to the method of Dougherty ${ }^{14}$ for serum as follows: supernatant was passed down a pd10 column (Sephadex G25 prepacked; Pharmacia) eluting with bovine serum albumin $(1 \%)$ in $\mathrm{NaC} 1(0.9 \%)$ with PMSF and TAME as above. This removed low molecular weight substrates and inhibitors. The supernatant $(0.2 \mathrm{ml})$ was incubated at $37^{\circ} \mathrm{C}$ with purified $\left[{ }^{14} \mathrm{C}\right]$ xanthine $(27 \mu \mathrm{M}$ xanthine, $\left[6-{ }^{14} \mathrm{C}\right]$ xanthine activity $1.9 \mathrm{MBq} / \mu \mathrm{mol}$, Amersham International) for three hours. In some incubations allopurinol $(0.1 \mathrm{mmol} / \mathrm{l})$ and $\mathrm{NAD}^{+}(0.7 \mathrm{mmol} / \mathrm{l})$ were included in the incubation solution. The reaction was stopped by the addition of trichloroacetic acid $(40 \mu \mathrm{l}, 40 \%)$, and after brief boiling to release bound uric acid, and centrifugation, the sample supernatant $(0.1 \mathrm{ml})$ was passed down a Dowex 50 ion exchange column $(5 \mathrm{~cm}$ Pasteur pipette column, eluant $0 \cdot 1 \mathrm{M} \mathrm{HC1}$ ) and the uric acid
Table 1 Xanthine oxidoreductase activity in human synovium*

\begin{tabular}{|c|c|c|c|c|}
\hline Sample & & $\begin{array}{l}+N A D^{+} \\
D+O \\
\text { form }\end{array}$ & $\begin{array}{l}-N A D^{+} \\
O \text { form }\end{array}$ & $\begin{array}{l}+ \text { Allo- } \\
\text { purinol }\end{array}$ \\
\hline Rheumatoid synovia & $\begin{array}{l}\text { A } \\
\text { B } \\
\text { C } \\
\text { D } \\
\text { E }\end{array}$ & $\begin{array}{l}305 \\
30 \cdot 8 \\
21 \cdot 5 \\
3 \cdot 0 \\
0 \cdot 67\end{array}$ & $\begin{array}{c}291 \\
25 \cdot 7 \\
23 \cdot 5 \\
3 \cdot 1 \\
0\end{array}$ & $\begin{array}{l}- \\
0 \cdot 34 \\
8 \cdot 22 \\
0 \\
0\end{array}$ \\
\hline Non-arthritic synovia & $\begin{array}{l}\text { A } \\
\text { B } \\
\text { C }\end{array}$ & $\begin{array}{l}5 \cdot 0 \\
3 \cdot 48 \\
1 \cdot 2\end{array}$ & $\begin{array}{l}4 \cdot 3 \\
3 \cdot 36 \\
1 \cdot 16\end{array}$ & $\begin{array}{l}0 \\
0 \\
0\end{array}$ \\
\hline
\end{tabular}

${ }^{*}$ Figures are expressed as $\mu \mathrm{U} / \mathrm{g}$ tissue.

traction collected and ${ }^{14} \mathrm{C}$ measured. Xanthine oxidase standards $(0-25 \mu \mathrm{U})$ were included in eacho experiment. Protease inhibitors were included at all $\underset{ }{\supset}$ stages of the assay to prevent loss of total activity $z$ and conversion of $D$ to $O$ forms of the enzyme, which in some instances is achieved with proteases.

\section{Results}

Non-arthritic synovia contained xanthine oxide. reductase $(5 \cdot 0-1 \cdot 2 \mu \mathrm{U} / \mathrm{g}$ tissue) which was larges independent of $\mathrm{NAD}^{+}(4 \cdot 3-1 \cdot 16 \mu \mathrm{U} / \mathrm{g}$ tissue without $\mathrm{NAD}^{+}$) and showed no detectable activity with allopurinol. Rheumatoid synovia contained more xanthine oxidoreductase $(305-0.67 \mu \mathrm{U} / \mathrm{g}$ tissue), $\mathbb{\mathbb { D }}$ which was also independent of $\mathrm{NAD}^{+}(291-0 \mu \mathrm{U} / \mathrm{g}$ tissue without $\mathrm{NAD}^{+}$) and showed little activity with allopurinol $(8 \cdot 22-0 \mu \mathrm{U} / \mathrm{g}$ tissue) (Table 1$)$.

\section{Discussion}

We have shown that xanthine oxidoreductase activ-묵 ity is present in human synovium in small but. detectable quantities. The enzyme was assayedô chiefly in its $O$ form, but as it is converted very? readily from its $\mathrm{D}$ to its $\mathrm{O}$ form during preparation and can be independent of proteolytic conversion $>$ this indicates simply that conversion to the $O$ form is possible.

The differences obtained between rheumatoid ${ }^{\circ}$ and non-arthritic synovial preparations may not be ${ }^{N}$ related to increases in intracellular enzyme levels ${ }_{\omega}^{N}$ but rather to the greater cellularity of the rheumatoid synovial preparations. It is for this reason thato we have not compared the groups statistically. $\frac{\mathbb{\Phi}}{\mathrm{C}}$ Attempts to overcome this problem by localising the? enzyme using a histological technique on frozent synovial sections have so far failed, possibly owing? to lack of sensitivity of the technique used. ${ }^{15}$ As 
most of the tissue obtained was from patients undergoing joint replacement the levels may be higher in active rheumatoid patients with less advanced disease. It has been reported that xanthine oxidoreductase is present chiefly in capillary endothelial cells, the enzyme being localised by immunological techniques. ${ }^{16}$ This would also fit in with our data in view of the increased vascularity of rheumatoid synovia.

Xanthine oxidoreductase has previously been detected in considerable quantities in rat air pouch carrageenan induced granuloma, ${ }^{17}$ an interesting observation in view of the structural similarities of the air pouch and the synovial lining. This difference reflects the difference found generally between rat and human xanthine oxidoreductase levels, humans having little of the enzyme in any tissue except liver $(30-150 \mathrm{mU} / \mathrm{g}$ tissue) and intestine $(29-56 \mathrm{mU} / \mathrm{g}$ tissue). Xanthine oxidoreductase levels in heart are of the same order as synovial levels $(0 \cdot 16-0 \cdot 38 \mathrm{mU} / \mathrm{g}$ protein). ${ }^{18}$

In addition to this potentially radical producing enzyme, rheumatoid synoviocytes contain high levels of iron saturated ferritin, and the $O$ form of xanthine oxidoreductase is capable of mobilising iron from ferritin by a mechanism largely dependent on superoxide ion. ${ }^{19}$ This release of iron together with the production of $\mathrm{O}_{2}^{-}$and $\mathrm{H}_{2} \mathrm{O}_{2}$ may lead to an iron catalysed Fenton type reaction with the formation of the highly reactive hydroxyl radical. The synoviocyte with high ferritin levels may be particularly susceptible to damage..$^{20-22}$

In conclusion, xanthine oxidoreductase is present in the synovial membrane and may contribute to synovial reperfusion injury directly by production of $\mathrm{O}_{2}^{--}$and $\mathrm{H}_{2} \mathrm{O}_{2}$ and by iron mobilisation. We are at present examining synovial fluids for changes in substrate and product levels resulting from exercise and subsequent rest.

CJM. DRB, and JMO, are supported by the Arthritis and Rhcumatism Rescarch Council. REA is supported by the British technology group.

\section{References}

1 Woodruff T, Blake D R, Frecman J, Andrews F J, Salt P. Lunec $J$. Is chronic synovitis an example of reperfusion injury? Ann Rheum Dis 1986; 45: 608-11.

2 Jayson $M$ I V. Dixon A St J. Intra-articular pressure in rheumatoid arthritis of the knee. III Changes during joint use. Ann Rheum Dis 1970; 29: 401-8.

3 Lund-Olsen K. Oxygen tension in synovial fluids. Arthritis Rheum 1970; 13: 769-76.

4 Jayson M I V, Dixon A St J. Intra-articular pressure in rheumatoid arthritis of the knee. II Effect of pressure on blood circulation to the synovium. Ann Rheum Dis 1970; 29: 266-8.
5 McCord J M. Oxygen derived free radicals in postischaemic tissue injury. New Engl J Med 1985; 312: 159-63.

6 Jennings $\mathrm{R} \mathrm{B}$, Reimer $\mathrm{K}$ A. Lethal myocardial ischaemic injury. Am J Pathol 1981; 102: 241-55.

7 Jennings R B, Reimer K A, Hill M A, Mayer S E. Total ischaemia in dog hearts. I. A comparison of high energy phosphate production, utilisation and depletion and of adenine nucleotide catabolism in total ischaemia in vitro. Circ Res 1981; 49: 892-900.

8 Della Corte E, Stirpe F. The regulation of rat liver xanthine oxidase: involvement of thiol groups in the conversion of the enzyme activity from the dehydrogenase (type D) to the oxidase (type O) and purification of the enzyme. Biochem J 1972; 126: 739-45.

9 Roy R S, McCord J M. Superoxide and ischaemia: conversion of xanthine dehydrogenase to xanthine oxidase. In: Greenwald R A, Cohen G, eds. Oxyradicals and their scavenger systems. Vol II. Cellular and medical aspects. New York: Elsevier, 1983: 145-53.

10 Granger D N, Hollworth M E, Parks D A. Ischaemiareperfusion injury: role of oxygen derived free radicals. Acta Physiol Scand 1986; 548: 47-63.

11 Zweier J L, Flaherty J T, Wiesfeldt M L. Direct measurement of free radical generation following reperfusion of ischaemic myocardium. Proc Natl Acad Sci USA 1987; 84: 1404-7.

12 Bernier M, Hearse D J, Manning A S. Reperfusion-induced arrhythmias and oxygen derived free radicals. Studies with antifree radical interventions and a free radical generating system in the isolated perfused rat heart. Circ Res 1986; 58: 331-40.

13 DeWall R A, Vasko K A, Stanley E L, Kezdi P. Responses of the ischaemic myocardium to allopurinol. Am Heart J 1971; 82: 362-70.

14 Dougherty T M. A sensitive assay for xanthine oxidase using commercially available ${ }^{14} \mathrm{C}$ xanthine. Anal Biochem 1976; 74: 604-60.

15 Auscher C, Amory N, Pasquier C, Dellbarre F. Localisation of xanthine oxidase activity in hepatic tissue. A new histochemical method. Adv Exp Med Biol 1977; 76A: 605-9.

16 Jarasch E D, Grund C, Bruder G, Heid H W, Keenan T W, Franke W W. Localisation of xanthine oxidase in mammary gland epithelium and capillary endothelium. Cell 1981; 25: 67-82.

17 Auscher C, Brouilhet H, Van der Kemp P, Rabaud M. Activité de la xanthine oxydase: formes $\mathrm{NAD}^{+}$-dépendante et oxygenedépendante dans le granulome à la carragénine chez le rat. $C R$ Seances Acad Sci [III] 1983; 297: 351-4.

18 Parks D A, Granger D N. Xanthine oxidase: biochemistry distribution and physiology. Acta Physiol Scand 1986; 548 (suppl): 87-99.

19 Biemond P, Swaak A J G, Biendorff C M, Koster J F. Superoxide-dependent and -independent mechanisms of iron mobilisation from ferritin by xanthine oxidase. Biochem $J$ 1986; 239: 169-73.

20 Morris C J, Blake D R, Wainwright A C, Steven M M. The relationship between iron deposits and tissue damage in the synovium: an ultrastructural study. Ann Rheum Dis 1986; 45: 21-6.

21 Blake D R, Gallagher P J, Potter A R, Bell M J, Bacon P A. The effect of synovial iron on the progression of rheumatoid disease. A histological assessment of patients with early rheumatoid arthritis. Arthritis Rheum 1984; 27: 495-501.

22 Morris C J, Wainwright A C, Stevens M M, Blake D R. The nature of iron deposits in haemophiliac synovitis. An immunohistochemical, ultrastructural and $\mathrm{x}$-ray microanalytical study. Virchows Arch [A] 1984; 404: 75-85. 